\title{
EFFECT OF DISASTER EMERGENCY RESPONSE EDUCATION ON KNOWLEDGE, ATTITUDE, PRACTICE, AMONG ISLAMIC BOARDING SCHOOL STUDENTS
}

\author{
Hamdy Alallah, Hanifa Maher Deni, Suroto \\ Masters Program in Occupational Safety and Health, Faculty of Public Health, \\ Universitas Diponegoro
}

\begin{abstract}
Background: Natural disasters such as earthquakes, tsunamis, and floods can often come at the least expected time. It causes injury, death, loss of livestock, property damage, and economic loss. School should be prepared to handle them safely and effectively by giving information about disaster emergency response. This study aimed to determine the effect of disaster emergency response education on knowledge, attitude, practice, among Islamic boarding school students.

Subjects and Method: This study was a quasi-experiment with one group pre-test and post-test design. This study was conducted at an Islamic boarding school, Semarang, Central Java. A total of 67 students was selected for this study. The independent variable was disaster emergency response education. The dependent variables were knowledge, attitude, and practice. The data were collected by questionnaire and analyzed by $t$ test.

Results: Knowledge, attitude, and practice on disaster emergency response increased after disaster emergency response education, and they were statistically significant.

Conclusion: Disaster emergency response education enhances knowledge, attitude, and practice on disaster emergency response.

Keywords: education, disaster emergency response, knowledge, attitude, practice

Correspondence:

Hamdy Alallah. Masters Program in Occupational Safety and Health, Faculty of Public Health, Universitas Diponegoro, Semarang, JL. Pucang Sari 7 No. 11 Batursari, Mranggen, Demak district 59567, Semarang, Central Java. Email: hams11488@gmail.com. Mobile: 085643872756 .
\end{abstract}

The 5th International Conference on Public Health Best Western Premier Hotel, Solo, Indonesia, February 13-14, $2019 \mid 181$ https://doi.org/10.26911/theicph.2019.02.26 